\title{
Cooks syndrome
}

INSERM

\section{Source}

INSERM. (1999). Orphanet: an online rare disease and orphan drug data base. Cooks syndrome. ORPHA:1487

Cooks syndrome is a malformation syndrome affecting the apical structures of digits and presenting with hypo/aplasia of nails and distal phalanges. More than half of digits are usually involved and the thumbs may appear digitalized. 